\title{
La recepción del derecho romano testamentario en las Partidas
}

Carmen Pujal Rodríguez

\section{INTRODUCCIÓN}

El hecho histórico de la extensión del derecho romano justiniano merced al impulso dado a los estudios jurídicos por la llamada escuela de los Glosadores es un acontecimiento de tal complejidad y amplitud que o bien requiere una extraordinaria capacidad de síntesis, si se tratara de exponer los rasgos estimados como esenciales, ' o bien una labor de equipo que depure y valore el gran número de datos conocidos e investigue al tiempo las zonas aún no exploradas. Hoy nadie duda que el genial esfuerzo de F. C. de Savigny que dio como resultado su admirable Historia del Derecho romano en la Edad Media no puede tener un continuador individual y no es extraño por tanto que las obras aparecidas o en trance de aparición a partir de la segunda mitad de este siglo tengan un carácter colectivo. Tal es el caso de la publicación aún inconclusa que conocemos con el nombre de IUS ROMANUM MEDII AEVI y que comenzó a publicarse en 1961 bajo los auspicios de la Société d'histoire de droits de l'antiquité. Pero sí trazar un cuadro general de lo que fue la recepción del Derecho romano en la Europa medieval tropieza con dificultades obvias, si es factible acotar una de las muchas parcelas que se pueden distinguir en ese inmenso campo y observar en ella los efectos concretos de aquel fenómeno general.

En el presente artículo y como se desprende del título, queda acotado un sector del Derecho privado - el Derecho testamentario y hay además una segunda limitación, esta de carácter geográfico, pues el estudio ha de referirse a lo ocurrido en Castilla. Otra frontera puesta de 
antemano se remite al marco cronológico pues será ese período que conocemos con el nombre de época bajo-medieval el preferentemente enfocado.

Otras precisiones, que han de verse sin duda como nuevos acotamientos, guardan relación con las fuentes examinadas. El campo a explorar va a quedar limitado a las Partidas, quedando en principio marginada la posible información que pueda contenerse en fuentes literarias o en documentos de la práctica. Aún con tales restricciones estimamos que el material sobre el que se asienta el presente trabajo es lo suficientemente rico como para extraer de él resultados significativos.

Ahora bien, para la debida comprensión de las fuentes que han de manejarse, y una vez que partimos del hecho indiscutible de que constituyen textos fuertemente influidos por el Derecho romano, parece necesario trazar previamente las características del Derecho que se iba a asumir, pues es evidente que en el renacimiento jurídico medieval no operan a un tiempo todas las normas y principios que tuvieron validez en el Derecho de Roma desde sus más remotas épocas hasta ese punto final que de común acuerdo todos los romanistas sitúan en el gobierno del emperador Justiniano. Es sabido que es precisamente el Derecho justinianeo el que tiene aquí significación y a él por tanto hemos de referirnos primordialmente, pues ninguno de los juristas medievales que intervinieron en la obra que hemos de considerar resulta presumible que pudiera conocer fuentes prejustinianeas o, en todo caso, si éstas llegaron a estar a su alcance no fueron tenidas en cuenta. Una primera parte, por tanto, del presente trabajo irá dedicada a la exposición del Derecho justinianeo en materia de testamento, precedente absolutamente necesario para la correcta interpretación de la fuente medieval de que luego habremos de ocuparnos. 


\section{1.-EL DERECHO TESTAMENTARIO JUSTINIANEO}

\section{1. - Sus precedentes inmediatos. Consideraciones sobre la sucesión mortis causa en época postclásica}

El Derecho justinianeo en su conjunto se nos presenta como el resultado de múltiples factores. En efecto, encontramos el Derecho clásico, el gran modelo que los juristas justinianeos siempre tuvieron presente, la tradición jurídica del Bajo Imperio, un pasado mucho más próximo y que, pese a su imperfección técnica, deja sentir sus efectos en los compiladores bizantinos, el helenismo y el cristianismo.?

El Derecho sucesorio no fue una excepción y cabe señalar, por tanto, respecto de él la existencia de esos factores. Una visión general de lo que fue la evolución de esa parte del Derecho tras el período clásico nos ayudará a centrar mejor el tema específico del Derecho testamentario justinianeo.

Es lógico que los profundos cambios económicos y sociales que se dieron en el tránsito del Principado al Bajo Imperio repercutieron necesariamente en el Derecho hereditario, lo mismo que había acontecido en otros sectores del Derecho privado. Estos cambios hicieron necesaria la intervención legislativa de los emperadores que se suceden tras Diocleciano. Aunque los caminos seguidos en Oriente y Occidente no siempre coincidieron, lo que se trasluce de esa legislación (y lo mismo cabría decir de la literatura jurídica postclásica) es la influencia ejercida sobre ella por corrientes como el vulgarismo y el clasicismo, así como por el helenismo y el cristianismo.

Las concepciones jurídicas vulgares afloraron sobre todo en Occidente consiguiendo que muchas particularidades del antiguo Derecho romano, que se habían mantenido en la época clásica, fueran eliminadas. Justiniano, por el contrario, aunque no ignorase que las circunstancias sociales y económicas de su tiempo eran distintas a las del Principado, procuró atenerse con una cierta fidelidad a las fuentes clásicas 
rehabilitando una serie de conceptos jurídicos que el vulgarismo había desechado. Los siguientes casos pueden servirnos como ejemplo.

La clasificación de los herederos en sui y extranei, fundamental en el Derecho clásico a efectos de la adquisición de la herencia y que en el Derecho vulgar de Occidente desaparece al sentarse el principio de que todos los herederos han de manifestar su aceptación, es rehabilitada por Justiniano. ${ }^{3}$ Lo mismo ocurre con la antigua regla según la cual nemo pro parte testatus por parte intestatus decedere potest. Desechada por el Derecho vulgar, Justiniano la actualiza, aunque la someta a algunas restricciones. ${ }^{+}$Como también recoge la vieja idea de la sucesión a título universal con el principio conexo de la necesidad en el testamento de la institución de heredero, criterios que habían sido abandonados en Occidente al acompasarse la evolución jurídica a las tendencias vulgares. Dentro de éstas se inscriben la confusión entre institución de heredero y legados, la indiferenciación entre testamento y codicilo y también la desaparición de toda diferencia entre legados y fideicomisos.

En otros puntos del Derecho de sucesiones no hubo sin embargo este contraste entre la postura justinianea y las tendencias vulgares postclásicas. Tal ocurre con el cambio de significación que experimenta el concepto de Falcidia, el cual de aludir en época clásica a la cuarta parte de la herencia que al menos había que reservar al heredero una vez detraídos los legados pasó a constituir la cuota (también de una cuarta parte) que debería quedar reservada a los herederos ab intestato que gozaban de la consideración de parientes más próximos. Un fenómeno éste que en Occidente condujo a una marcada limitación de la libertad de testar que ha llegado hasta nuestros días. Ahora bien el cambio de significación afectó también al Derecho bizantino. ${ }^{6}$

Se han de destacar también como rasgos de este tardío Derecho hereditario que va formándose bajo la presión de las nuevas circunstancias sociales: a) la mejor posición jurídica de la mujer en orden a su capacidad sucesoria; ${ }^{7}$ b) el declive de los vínculos agnaticios, con la incidencia que ello tenía en las relaciones de dependencia de los filii, los cuales van a ver también reconocida una cierta capacidad sucesoria al 
haberse admitido que pueden ser patrimonialmente capaces; ${ }^{8} \mathrm{c}$ ) la posibilidad de que algunos patrimonios pasen a las comunidades o corporaciones a las que pertenecía el causante (a la unidad militar si el causante había sido un soldado perteneciente a ella, a la corporación profesional si había sido un miembro de la misma, y sobre todo a la Iglesia o al Monasterio correspondiente si el difunto era un Obispo, un Clérigo o ùn Monje). ${ }^{9}$

Pero junto a esas notas características hay otros rasgos que cabe señalar y que nos sirven para dibujar mejor el contraste entre este Derecho tardío y el que había tenido vigencia en los tiempos clásicos. Así el relativo a la postergación de la sucesión testamentaria frente a la intestada. El progresivo empobrecimiento de amplios sectores de población puede explicar tal fenómeno. Durante la República y durante el Principado la extensión y primacía de la sucesión testada tuvo sin duda su base en las especiales condiciones económicas y sociales que conocieron aquellos períodos. Un extenso círculo de personas pertenecientes a los sectores económicamente más poderosos tuvo una fuerte inclinación a favorecer tras su muerte a las gentes de su entorno, comprendiendo entre los favorecidos no sólo a los que tenían la consideración de parientes más próximos, sino también a los que eran simplemente amigos o estaban en una posición social o política que movía a la devoción y al respeto. Los móviles podían ser diversos, desde la mencionada veneración o el deseo de vincular moralmente al beneficiado para un comportamiento futuro, hasta la mera gratitud o un mero impulso emotivo de cualquier género. En el Bajo Imperio, las condiciones sociales y económicas habían cambiado y ello influyó probablemente en esta postergación del testamento. ${ }^{10}$ Pero, además, surgió una nueva corriente que puede verse como una exigencia del ahora extendido sentir cristiano y que no es otra que la de procurar la salvación del alma disponiendo de todo el patrimonio o de parte de él. Esas disposiciones se hacían tanto inter vivos como mortis causa, en favor de Dios, de Cristo, de los Ángeles, de los mártires, etc. y dejando el patrimonio a la Iglesia o a algún convento. En otras ocasiones la atribución se hacía fijando además una finalidad piadosa (rescate de cautivos, socorro de necesitados, etc.). 
Por otro lado es un hecho sabido que el formalismo que aún impregna el Derecho testamentario de la época clásica decae considerablemente a partir de Constantino, tanto en lo que se refiere a la institución de heredero como a las restantes disposiciones. Se renuncia así a la exigencia de que la institución de heredero encabece el testamento y llega incluso a aceptarse que tal cláusula falte, con lo que la confusión entre testamento y codicilo se hace inevitable. También en este punto Justiniano procederá a señalar de nuevo la distinción que había caracterizado al Derecho clásico.

En cuanto a otros requisitos formales la distinción que aparece en el siglo IV, según la cual hay testamento que requiere siete testigos, forma que se dice establecida por el ius civile, mientras que hay otros, atribuidos al ius praetorium, que sólo exigen la subcripción de cinco testigos, permanecerá hasta la disposición reformadora de Teodosio II (Novellae Theadosiani $16=$ C.6.23.21). Mucho se ha discutido a propósito de esta persistente dualidad en una época en la que la diferencia entre ius civile y ius praetorium carecía ya de sentido, no teniendo tampoco significación alguna la correlativa distinción entre hereditas y bonorum possessio. Pero sin que se pueda decir que la hipótesis sea aceptada por todos los romanistas quizás la diferencia que se establece entre una y otra forma de testar guarde relación con el carácter "cerrado» o "abierto» de la declaración prestada." En todo caso la citada constitución de Teodosio II del año 439 sienta las bases de un nuevo testamento y a esas pautas vendrá a ajustarse el Derecho justinianeo.

Otro punto que merece ser destacado aquí y que antes fue simplemente esbozado es el de la distinta suerte que en Oriente y en Occidente corrió una concepción que había sido básica en la herencia del Derecho clásico. En éste, como es sabido, la herencia fue concebida como un succedere in universum ius defuncti, lo que significaba que se pensaba en un conjunto patrimonial unitario por encima y con independencia de los bienes concretos que lo compusieran. En Occidente, al desmoronarse las estructuras básicas del Derecho hereditario clásico se fue esfumando también la idea de la sucesión universal para dar paso a la imagen de una sucesión en derechos o bienes individualizados. Por el contrario en Oriente se mantuvo una mayor fidelidad a la concepción clási- 
ca y se insistió por tanto en la visión de la herencia como un fenómeno de continuidad en la titularidad jurídica de un unitario conjunto patrimonial.

\section{2.-Posición concreta de Justiniano en materia de testamento}

Si nos atenemos al específico campo de las formas testamentarias conviene añadir, a lo que ya antes ha sido señalado, cuál fue la actitud del derecho postclásico pues es ésta, junto con las tendencias clasicistas, la que explica la posición de Justiniano.

El contraste entre el Derecho clásico y el que empieza a observarse a partir ya de Constantino es evidente. Este emperador decide abolir las formas solemnes permitiendo testar tanto oralmente como por escrito siempre que se hiciera ante testigos. Con ello dejó de ser exigido el rito per aes et libram y las formas de la nuncupatio del testamento civil, ${ }^{2}$ lo cual trajo consigo que el testamento civil se acercarse al testamento pretorio de tal manera que la diferencia entre ambos venía a quedar reducida a que en uno se necesitaban cinco testigos mientras que en el otro hacian falta siete $^{13}$

Lo lógico hubiera sido eliminar la exigencia de los siete testigos, pero se mantuvo en la práctica la duplicidad como lo demuestra el hecho de que las constituciones imperiales posteriores a Constantino sigan refiriéndose el testamento civil y al testamento pretorio. ${ }^{14}$

Una constitución de Arcadio y Honorio del 396 (CTh.4.4.3) parece haber dejado en libertad al testador para adjetivar el testamento como quiera con independencia de los testigos que intervengan en el acto. En todo caso el número de éstos exigido es el de cinco sin que se requiera que tengan noticia del contenido del testamento aunque sí deban saber que su comparecencia es a efectos testamentarios. En el 424 Teodosio II ${ }^{15}$ decide que los testigos han de estar presentes cuando el testamento se redacta teniendo que quedar cumplido el acto en el plazo máximo de un día; con lo que la pretensión de mantener en secreto el contenido de la voluntad testamentaria queda notablemente obstaculizada.

Los testamentos a que aluden esas constituciones son sin duda testamentos escritos pero ello no contradice la persistencia en época post- 
clásica de los testamentos orales. Con el nombre usual de nuncupationes siguen siendo mencionados en disposiciones contenidas en el Código Teodosiano, en constituciones post-teodosianas y en la propia interpretatio. ${ }^{16}$

Pero la legislación de Teodosio II en materia de testamentos no se agotó con la referida constitución de 424. En una nueva disposición promulgada en el año 439 (Novella XVI) rectifica el Derecho anterior desde el momento en que permite que pueda ser presentado ante los testigos un documento cerrado siempre que se indique que en él se contiene el testamento. En tal supuesto los testigos, que han de ser siete (u ocho si el testador es analfabeto) han de firmar y sellar el documento. ${ }^{17}$ Por otro lado el testamento oral requiere la presencia de siete testigos (Nov. Valent. XXI 2).

Además, en época postclásica aparece un testamento público que presenta dos modalidades: apud acta y principi oblatum. El otorgado apud acta supone una declaración ante un juez público, mientras que el testamentum principi oblatum necesita la presentación al emperador del escrito en que se contiene la última voluntad, documento que tras cumplida esa formalidad pasa a ser archivado entre los fondos a cargo del magister libellorum. Esta última forma de testamento público fue introducida por una constitución de Arcadio y Honorio y Teodosio del año 413. ${ }^{18}$ En cuanto al testamentum apud acta no sabemos cuándo fue aceptado, pero sí que estaba en vigor cuando la referida constitución del 413 fue promulgada, pues en el texto de ella se lo da por existente.

Sobre los precedentes reseñados Justiniano construyó su propio derecho testamentario mostrando una clara voluntad de aceptar en líneas generales esa tradición inmediata. Nada innova en materia de testamentos públicos y tampoco introduce modificación alguna en lo que atañe al testamento oral. Sin embargo, no acepta el testamento ológrafo que Valentiniano III había introducido en Occidente. ${ }^{19}$

En el testamento privado escrito las precisiones introducidas fueron las siguientes.

En lo que se refiere a la requerida unidad de acto en el otorgamiento ante testigos se alejó de una interpretación rígida permitiendo que 
pudiera haber algún intervalo entre un trámite y otro de los que componen la serie que conduce a la culminación del negocio. Por ejemplo, sería tenida como irrelevante una moderada interrupción de las actuaciones tras la subscriptio del testador y antes de que pusieran sus sellos los testigos. Es lo que determina en una constitución del 530 (C.6.23.28). Por otra parte, y tal como las propias Instituciones justinianeas recuerdan (I.2.10.6), al igual que en la época clásica continuaron siendo incapaces para actuar como testigos las mujeres, los impúberes, los sordos, los mudos, los esclavos, los que sufren de enajenación mental, los que por pródigos tienen vedada la administración de sus bienes y los que por ley son improbi et intestabili. En cuanto a la distinción entre testamentos ológrafos y alógrafos, Justiniano, que no aceptó la forma de testamento ológrafo reconocido en Occidente y a la que antes aludimos, sí dispuso que cuando el documento estuviera escrito por la propia mano del testador no hiciera falta la subscriptio de este (C.6.23.28.1). De estar escrito por otro sería por el contrario necesario no sólo esa subscriptio, sino también que el testador escribiera por sí mismo el nombre del heredero y la cuota hereditaria que pudiera corresponderle y, en el caso de que no supiera escribir o no pudiera hacerlo, un octavo testigo tendría que realizar ese cometido (C.6.23.29; I.2.10.4).

En las Instituciones justinianeas (1.2.10.3) se da al testamento privado el nombre de tripertitum exponiéndose que la razón de tal calificación estriba en que entran en él tres ingredientes procedentes de épocas pasadas: el ius civile (del cual se deriva la exigencia de que intervengan testigos), el edicto del pretor (que impuso el número de testigos y los sellos) y las constituciones imperiales (que determinaron la necesidad de las subscriptiones respecto de testador y testigos).

Esta breve caracterización del Derecho justinianeo quedaría incompleta si no fuera también aludida una cuestión que si bien a primera vista parece que no atañe a la esencia del Derecho testamentario de la época no es en realidad tan ajena a él. Se trata de la materialidad de las normas que afectan a esa rama del ordenamiento, normas que, como es sabido, tienen una variada procedencia pero que, en todo caso, se sitúan en determinados lugares de la gran compilación. Veamos pues la localización de estas normas. 
Lo primero que se comprueba tras la consulta del Corpus iuris es que las normas que se refieren propiamente el testamento como acto dispositivo - y no a cláusulas particulares como puedan ser legados, fideicomisos o manumisiones o designaciones de tutor hechas por vía testamentaria - se contienen en las Instituciones y en el Código (I.2. 10: De testamentis ordinandis; C.6.23: De testamentis: quemadmodum testamenta ordinantur). Desde luego el Digesto no ignora el derecho testamentario, ${ }^{2(1)}$ y hasta se ocupa $(D .28 .1)$ de requisitos que no deben faltar para el otorgamiento de un testamento válido, pero se comprende que, habiendo sufrido las formas testamentarias tan notables cambios en el período postclásico, las obras de los juristas del Principado fueran en este punto inaplicables en gran medida y que la selección de los correspondientes fragmentos se llevase a cabo desechando aquellas disquisiciones que tenían en cuenta la forma del testamento clásico.

En los sectores básicos aludidos - Instituciones y Código- es donde se presenta abiertamente la concepción justinianea del testamento, pero ha de tenerse presente la desigual fisonomía que ambas fuentes presentan. Refirámonos pues separadamente a una y a otra.

\section{INSTITUCIONES}

En el aludido título De testamentis ordinandis está desde luego, como en otras muchas partes de la obra, la huella dejada por las Instituciones gayanas, pero hay que reconocer también que no hubo, ni podía haberla, una total transcripción del modelo clásico. El título contiene una introducción donde viene a explicarse el significado de la palabra testamentum (pr.: testamentum ex eo appellatur, quod testatio mentis est) para exponer acto seguido una breve historia $(\$ \S-4)$ de las formas testamentarias desde los tiempos más remotos hasta la propia época de Justiniano. Los párrafos siguientes $(\$ \S-11)$ plantean desde diversos ángulos el problema de quiénes pueden ser testigos idóneos, dedicándose los últimos $(\S \S-14)$ a la no exigibilidad de una materia especial como base de escritura, a la posibilidad de que se redacten varias copias y a la validez del testamento oral.

No hay que olvidar sin embargo que el Derecho testamentario ocupa en las Instituciones justinianeas una zona más extensa que la repre- 
sentada por ese título De testamentis ordinandis. Tras él aparecen, como es sabido, otros quince ${ }^{21}$ que se remiten directamente al Derecho de los testamentos o que guardan relación con este sector del Derecho hereditario. Pero el título De testamentis ordinandis es el que sirve de introducción y base y el que por su contenido, y a los fines del presente trabajo, ofrece una primordial importancia.

\section{CÓDIGO}

El Derecho testamentario, en su más amplio sentido, viene a concentrarse en el libro VI pues es allí donde a partir del título 21 (De testamento militis) y hasta el título 54 (Ut in possessionem legatorum vel fideicommisorum servandorum causa mittatur et quando satisdari debet) se atiende a las diversas cuestiones que plantean los testamentos. No se enfocan por lo tanto solamente problemas de forma en cuanto al otorgamiento, sino también los relativos a la capacidad de testar, a la institución de heredero, a las sustituciones y desheredaciones, a la adquisición de la herencia deferida testamentariamente, a la apertura de testamentos, a las disposiciones singulares contenidas en estos (legados y fideicomisos), etc. Pero, como en las Instituciones, de ese conjunto de títulos el que a los fines del presente trabajo nos interesa preferentemente es el aludido título 23 (De testamentis: quemadmodum testamenta ordinantur).

El título contenía treinta y dos constituciones pero hoy sólo podemos leer treinta y una pues la última, la que debería llevar el número 32 , no la han conservado los manuscritos a nuestra disposición. ${ }^{22} \mathrm{De}$ las restantes la más antigua viene atribuida a Adriano y a ella siguen dos de Alejandro, una de Gordiano, una de Valeriano y Galieno, nueve de Diocleciano y Maximiano, una de Constancio, ${ }^{23}$ una de Graciano, Valentiniano II y Teodosio, dos de Arcadio y Honorio, dos de Honorio y Teodosio II, una de Teodosio II y Valentiniano III, una de Zenón y una de Justino. A continuación están las que proceden del propio Justiniano, y que son las comprendidas entre la 24 y la 31 , las cuales abarcan un período que va del año 528 al 534. Además de la distinción que puede hacerse entre constituciones prejustinianeas y constituciones justinianeas, respecto de las primeras cabe también distinguir entre aque- 
llas que eran rescriptos, es decir, decisiones provocadas por consultas hechas por los particulares a la cancillería imperial, teniendo este carácter las catorce primeras del título, y aquellas otras que iban dirigidas al pueblo en general o a altos dignatarios imperiales (constituciones 15 a 23). Los diferentes orígenes y pretensiones de las disposiciones que contiene el título no impiden sin embargo que éste sea considerado en su conjunto como derecho justinianeo pues Justiniano, al seleccionar para su Código constituciones de emperadores anteriores, vino a expresar su voluntad de que las normas que éstas contenían continuaran rigiendo en su tiempo; y aunque los rescriptos reflejaban aún el casuismo característico de esta clase de decisiones, también es cierto que de ellos se desprendían las exigencias que pesaban sobre quien quería otorgar un testamento válido permitiendo distinguir qué defectos de forma eran irrelevantes y cuáles no. ${ }^{24}$ En cuanto a las constituciones que no son rescriptos (las aludidas 15 a 23) son de destacar la 15 , la 19 y la 21 , en razón a que en ellas se aceptan disposiciones importantes en orden a la confección de testamentos (en la const. 15 se aceptaba la eliminación de toda solemnidad en la institución de heredero; en la 19 quedaba consagrado el testamento público conocido con el nombre de testamentum principi oblatum, y en la 21 se recogía la regulación referente a algunos tipos $^{25}$ de testamento). En sus propias constituciones Justiniano se limitó, en aras de la seguridad jurídica, a determinar con mayor precisión algunos puntos no suficientemente aclarados por el Derecho anterior (apertura oficial de testamentos, eliminación de cualquier formalidad - excepto la necesaria presencia de los siete testigos - en el testamento nuncupativo, revocación, unitas actus, exigencia de firmas de testigos y testador, intervención expresa de este mediante propia escritura o declaración oral en la designación de heredero, testamentos otorgados en ambientes rústicos) y por lo tanto sus disposiciones no tienen un carácter fuertemente innovador. 


\section{2.-EL DERECHO ROMANO TESTAMENTARIO EN LAS PARTIDAS}

\section{1.-Las Partidas: su Derecho Testamentario}

Las Partidas constituyen uno de los grandes cauces por donde penetra el Derecho Romano justinianeo en la España medieval, pero no sería exacto considerar a la obra legislativa del rey castellano Alfonso X como una traducción al romance del Corpus iuris. El Derecho contenido en la gran compilación de Justiniano influyó sin duda ninguna de modo muy notable en la obra castellana, pero ni fue recibido sin más, ni constituyó el único elemento que sirvió de base para esta colección jurídica. En lo que se refiere al Derecho testamentario el examen comparativo entre la regulación que contiene el Corpus iuris y la que fijaron las Partidas permite ver cómo y en qué medida aquella legislación del siglo VI revivió en la Castilla de la Baja Edad Media.

En el Código alfonsino es la sexta Partida la dedicada al Derecho sucesorio. Al frente de ella, y a modo de introducción, se justifica el tratamiento de esta rama del Derecho y se expone a grandes rasgos cuáles son los temas que se van a tratar.

Sesudamiente dixieron los sabios antiguos que pasan su tiempo aquellos que mientra viven facen bien su facienda, tomando guarda en las posturas et en los pleytos que ponen unos con otros: et mucho más mayormiente tovieron que habien grant seso los que á su finamiento sabien ordenar et poner lo suyo en tal recabdo de que ellos rescebiesen placer et feciesen pro de sus almas, et fincando despues de su muerte lo suyo sin dubda et sin contienda á sus herederos. Onde pues que en la quinta Partida deste libro fablamos de todas las posturas, et pleytos et convenencias que los homes facen entre sí en su vida, queremos aqui decir de los testamentos que facen á su fin, porque esto es encerramiento de su fecho: et desi diremos de las herencias que los otros heredan dellos despues que mueren, tan bien por testamento como por manda ó por otra manera qualquier. Et otrosi mostraremos de cómo los huérfanos, et los niños chiquiellos et sus cosas deben seer guardadas et puestas en recabdo despues de muerte de sus padres, et de todas las otras cosas que pertenescen á estas razones. 
En su conjunto la Sexta Partida tiene 19 títulos pero, si descontamos los que aparecen dedicados a la «guarda de los huérfanos» -inspirados en la tutela impuberum del Derecho romano - que son los cuatro últimos (16 a 19) - son sólo 15 los consagrados al Derecho hereditario. Si se piensa en lo que había ocurrido en el Derecho vulgar de Occidente y en la huella que éste deja en la Alta Edad Media no deja de sorprender la atención que en esos quince títulos se presta al Derecho testamentario pues son doce los que se ocupan de esta rama del derecho sucesorio y solamente tres (el 13, el 14 y el 15) los dedicados a la sucesión abintestato, o conjuntamente a ésta y a la sucesión por testamento. ${ }^{26}$

El título que requiere un interés más acusado en razón al trabajo presente es, desde luego, el título I (Que cosa es testamento) ya que en él se habla de la noción misma de testamento y de las solemnidades que son precisas para un otorgamiento válido. He aquí las materias o puntos que, según el sumario que antecede al título, iban a ser desarrolladas a continuación:

Testamento es una de las cosas del mundo en que mas bien deben los homes
haber cordura quando lo facen, et esto es por dos razones: la una porque
en ellos muestran quál es la su postrimera voluntat, et la otra porque despues
que los han fecho, si se mueren, non pueden otra vez tornar á endereszarlos
nin á facerlos de cabo. Onde pues que en el comienzo desta Partida fecimos
emiente dellos, queremos decir en este título de la guarda que deben haber
los homes quando los quisieren facer: et mostrar qué quiere decir testamen-
to: et á qué tiene pro: et cuántas maneras son dél: et cómo debe seer fecho:
et quáles non pueden seer testigos en él: et quién lo puede facer et quándo:
et por qué razones se puede desatar: et qué pena deben haber los que embar-
gan á otros que lo non fagan.

En la ley 1, y dejando a un lado la inicial cuestión de la procedencia de la palabra testamento ${ }^{27}$ así como aquellas frases o expresiones con las que se pretende destacar la importancia de este acto de última voluntad, hay puntos que merecen ser destacados. El primero se refiere a la mención explícita de la institución de heredero («...estableciendo en él su heredero...»). El segundo a la clasificación que se expone de las formas que existen para otorgar un testamento ordinario: el testamentum nuncupativum y el testamentum in scriptis, una dualidad de 
formas que, es preciso reconocerlo, no queda trazada con suficiente claridad.

Si nos atenemos a la letra de la ley, testamento nuncupativo «quiere tanto dezir como manda que se faze paladinamente ante siete testigos, en que demuestra el que lo faze, por palabra o por escripto, a quales establesce por sus herederos e como ordena e departe las otras sus cosas». El otro, el testamentum in scriptis, es «como manda que se faze por escripto, e non de otra guisa». De lo que podría deducirse que la diferencia entre ambas formas testamentarias estribaría en que el testamento in scriptis no necesitaría los siete testigos ni la institución de heredero. Sin embargo, a esta interpretación se opone, en cuanto a la necesidad de los testigos, lo que la misma ley dice a continuación, y, en cuanto a la institución de heredero, el título III de esta misma Partida Sexta no deja lugar a duda sobre el carácter esencial de esta cláusula en cualquier tipo de testamento. 28

La diferencia pues, no puede establecerse sobre esa base. Pero también sería absurdo pensar que la separación entre ambas formas se redujera a la imposibilidad de que el testamento in scriptis se hiciera oralmente, pues en tal caso no parece comprensible la coexistencia de este testamento con el nuncupativo "que se faze por escripto».

No se ve otra explicación que la de aceptar que cuando un testamento nuncupativo constaba por escrito es que había habido una previa declaración oral del testador sobre el contenido de su última voluntad o que en el mismo momento de la redacción del escrito hacía pública verbalmente ante los testigos tal declaración. Esta parece ser en efecto la única explicación posible si hemos de desechar la absurda modalidad de un testamento al que se le da el nombre de nuncupativo pero en el que la voluntad del testador aparece solamente por escrito, una falta de lógica que se acrecienta además con la presencia de la otra posible forma testamentaria, la del testamento in scriptis, con la que vendría a coincidir.

Aunque ésta parece la única interpretación, cabría también enfocar el problema desde otro punto de vista, esto es, sentando la hipótesis de que el texto de esta ley 1 ha sufrido una torpe manipulación consistente 
en el añadido de las palabras «o por escripto» en la frase que trataba del testamento nuncupativo. ${ }^{29}$ Pero la Academia de la Historia, en la edición de las Partidas que realizó en 1907, no registra la existencia de manuscritos donde esas palabras fueran omitidas, y, por otro lado, tampoco puede sorprender demasiado que en el momento de redactarse esa ley 1 se quisiera hacer de pasada una mención a la posibilidad de que la voluntad expresada oralmente constara además en un documento escrito.

Conviene también destacar que las exigencias que se señalan en la segunda parte de esta ley (a partir de la expresión «E tal testamento como este...») se supone que van solamente referidas al testamento in scriptis. Estas exigencias afectan en primer término a la cualidad de los testigos (no se admiten esclavos, mujeres, menores de catorce años ni nombres «mal enfamados»). ${ }^{30}$ Estos, que han de ser siete lo mismo que en el testamento nuncupativo, han de cumplir en el acto las diligencias que se señalan, es decir, han de escribir sus nombres al fin del testamento y poner sus correspondientes sellos «con cuerdas pendientes». ${ }^{31} \mathrm{Ha}$ de cumplirse además el requisito de que el propio testador añada al final su nombre con la indicación de la naturaleza del escrito ( Yo, Fulano otorgo que fize este testamento en la manera que es escrito en esta carta»), aunque se admita, para el caso de que no pudiese o no supiese escribir, que lo hiciese otro «por mandato dél».

De todas maneras, y aunque es claro el reconocimiento de las dos formas testamentarias, la oral y la escrita, las Partidas parecen sentir una mayor inclinación hacia la última pues el testamento nuncupativo, tras haber sido mencionado en la ley $1 .^{a}$, no vuelve a ser objeto de especial alusión en el resto del título o en cualquiera de las leyes que integran la Partida Sexta. La forma testamentaria que parece estar presente en la amplia regulación que contiene esta Partida es la correspondiente al testamento in scriptis. También es esta forma la que se tiene en cuenta en los modelos de escrituras que pueden leerse en el título 18 de la Partida Tercera. En la ley 103 (Como deven fazer la carta del testamento) el modelo correspondiente no muestra variante especial para el supuesto de que el testador quisiese expresarse de palabra aunque aceptase también una redacción escrita de lo dicho. Las instrucciones que se 
contieneri se refieren a la expresión de disposiciones o cláusulas reputadas como esenciales o importantes (institución de heredero, desheredaciones, nombramiento de tutor para hijos menores, etc.) y también a diligenciás que no deben descuidarse, como por ejemplo, la declaración del testador «a la fin del testamento»:

«...yo Estevan Fernandez, el sobredicho, quiero e mando que este mi testamento e esta mi postrimera voluntad sea valedera por siempre jamás. E otorgo e quiero que todo testamento, o manda, que oviesse yo fecho ante què éste que sea cancelado e non vala: fueras ende si en él fiziesse señaladamiente mención de este testamento diciendo que lo revocava todo, o alguna partida dél.»

O la indicación hecha por el escribano de:

«...en qué lugar fue fecho el testamento e ante quáles testigos: e el dia e el mes e la era.»

Pero, como queda indicado, no hay instrucciones especiales para el supuesto de que el escribano estuviera presente en un testamento nuncupativo, como sí las hay por el contrario para el caso de que el testador desease mantener en secreto su última voluntad.

Después de exponer en la ley $1 .^{a}$ las dos referidas formas de testamento, y habida cuenta de la variante que representa, dentro del testamento in scriptis, el testamento cuyo contenido no conocen los testigos $^{32}$ y a la que la ley 2 se refiere expresamente,,$^{33}$ el resto del título aborda problemas variados pero entre ellos hay puntualizaciones sobre el tema que aquí nos interesa.

En efecto, las dos primeras leyes tratan de las formas esenciales que ha de revestir un testamento ordinario, es decir, subrayan la necesidad de que el testador haga la declaración ante siete testigos y cómo han de figurar los testimonios de éstos en el escrito que se redacte si es que se sigue la modalidad del testamento in scriptis. Pero lo mismo que había ocurrido en el Derecho romano, el cumplimiento de unas formas esenciales no eliminaba los resquicios por donde pudiera penetrar una impugnación basada en defectos formales. No puede extrañarnos así que algunas leyes de las Partidas, siguiendo los pasos del Derecho romano justinianeo, apunten a una clarificación de las causas de impug- 
nación por incumplimiento de las formalidades necesarias. Dejando ahora fuera de nuestra atención las normas que se refieren a la idoneidad de los testigos (no hay duda de que un testamento sería formalmente defectuoso, y por tanto inválido, si, por ejemplo, se probase luego que entre los testigos había una mujer) fijémonos en dos leyes, la 3 y la 12, que parecen redactadas para cerrar el paso a alegaciones de nulidad por defecto de forma.

La ley 3 se refiere a la unitas actus en el otorgamiento:

Comunalmiente deben guardar como por regla los homes que quieren facer sus testamentos, que pues que los han comenzado ante los testigos, non metan entremedias otros fechos extraños fasta que los hayan acabados, fueras ende si lo hobiesen á facer por cosa que non podiesen excusar, asi como si el dolor de la enfermedad los acuitase á aquella sazon, ó si hobiesen grant meester de comer, ó de beber ó de facer otra cosa que naturalmiente non se podiesen della desviar; ca por qualquier destas razones bien podrie el facedor del testamento partir mano de lo que habie comenzado fasta que aquel embargo pasase, et desi tornar á acabarlo.

Como puede observar quien haya leído previamente la constitución de Justiniano que ya fue antes mencionada (C.6.23.28), el texto castellano está dentro de la misma línea que la disposición justinianea, aunque se muestre más parco en el detalle. ${ }^{34}$ En ambos casos de lo que se trata es de impedir que prosperen impugnaciones basadas en cualquier interrupción del acto testamentario por leve que ésta fuera.

La ley 12 elimina también objeciones que pudieran producirse como consecuencia de haberse realizado la escritura del testamento en materiales supuestamente inadecuados.

En pargamino de cuero ó de papel, ó en tablas, quier sean de cera ó de otra manera ó en otra cosa en que se pueda facer escriptura et parescer, puede seer escripto el testamento. Et aun decimos que de un testamento puede home facer muchas cartas de un tenor, et destas cartas puede el testador levar la una consigo, et las otras puede poner en algunt logar seguro, asi como en sacristania de alguna eglesia, ó en guarda de algunt su amigo. Et estas cartas deben seer fechas en una manera, et seelladas de unos mesmos seelos, et de tantos la una como la otra, de guisa que acuerden las unas con las otras; pero si alguna dellas fuese menguada non empescerie á las otras que fuesen complidas. 
También aquí el precedente es claro. Justiniano en sus Instituciones ya había establecido (I.2.10.12) que la materia empleada podía ser cualquiera:

Nihil autem interest, testamentum in tabulis an in chartis membranisve vel in alia materia fiat.

Lo que por otra parte, no dejaba de ser congruente con el papel secundario que en virtud del tradicionalismo romano aún tenía la escritura en el Derecho justinianeo hasta el punto de que destruida ésta (y salvo en aquellos casos en que quien destruyese fuera el propio testador) si la declaración testamentaria podía ser conocida por otros medios no dejaría de operar sus efectos. Justiniano así lo había aceptado al acoger la constitución de Alejandro del 226 y la de Diocleciano y Maximiano del 293 en su Código (C.6.23.2 y 10).

La conclusión que cabe pues extraer de las leyes de las Partidas hasta aquí contempladas es que el Derecho romano justinianeo fue tenido muy en cuenta para llegar a su redacción.

El influjo de este Derecho puede percibirse también en otras áreas próximas a ésta; así ocurre con los TESTAMENTOS ESPECIALES que serán estudiados en el apartado siguiente.

\section{2. - Testamentos especiales en Las Partidas}

Además del testamento normal, en el que es necesaria la presencia de siete testigos, llamados por el testador, mayores de catorce años, que no sean siervos suyos, excluyendo también a las mujeres y a los que han caído en infamia, existen otros testamentos especiales, para los que se establece una forma distinta de la ordinaria y cuyos requisitos se agravan o se aligeran con arreglo a las circunstancias que concurran en ellos.

La ley 4, en el mismo título I de la Partida Sexta, se refiere a cómo pueden hacer testamento los caballeros:

Queriendo facer testamento algunt caballero, si lo feciese en su casa ó en otro logar que non sea en hueste, débelo facer en la manera que los otros homes, asi como dice en la ley ante desta: mas si lo hobiese de facer en hueste, entonce abonda aue lo faga ante dos testigos llamados et rogados para esto. Et 
si por aventura seyendo en la facienda et veyendose en peligro de muerte quisiere á aquella sazón facer su testamento, decimos que lo puede facer como quisiere et como podiere, por palabra et por escripto, et aun con la su sangre mesma, escrebiéndolo en su escudo ó en alguna de sus armas, ó señalándolo por letras en tierra, ó en arena; ca en qualquier destas maneras que lo él faga et pueda seer probado por dos homes bonos que se acertasen hi, vale tal testamento. Et esto fue otorgado por previllejo á los caballeros por les facer honra et mejoria mas que á los otros homes, por el grant peligro á que se meten por servir á Dios, et al rey et á la tierra en que viven.

Parece ser este testamento una derivación del Testamentum militis, testamento permitido a los militares, en el que se aplica un régimen de amplia libertad en contraposición a todas las formalidades que regían en la sucesión testamentaria ordinaria.

En cuanto a la forma, se implanta una amplísima libertad formal, permitiéndoles testar de cualquier modo, con tal que resultase que habían querido expresar su última voluntad.

La libertad de testar, con las expresadas características, se limitaba sólo a los militares que no estuviesen en su residencia habitual por hallarse en guerra.

Aquí vemos un precedente claro en las Instituciones de Justiniano; ${ }^{43}$ dicho Emperador, restringió la amplísima libertad de testar que tenían todos los militares, durante el Principado, limitándola aquellos que no estuviesen en su residencia habitual, sino «in expeditionibus ocupati». Si el testador era licenciado, la validez del testamento militar, duraba sólo un año a partir de la fecha del licenciamiento, y si éste habíase fundado en motivos deshonrosos, la ineficacia del testamento militar coincidía con la del licenciamiento.

El testamento, hecho con arreglo a la forma ordinaria de una persona civil, si después se hacía militar, puede, por voluntad del testador, convertirse en testamento militar.

La ley 5 se refiere al testamento especial de aquellos que, sin tener capacidad, el Rey les otorga poder para hacerlo, así como de la validez del testamento del que es testigo el Rey. 
Por derecho et por ley es defendido á algunos homes que non puedan facer testamento, et acaesce á las vegadas que los emperadores ó los reyes por les facer bien et merced que les otorgan poderio de lo facer: et en tal caso como este decimos, que este á quien es otorgado debe facer su testamento en la manera que lo facen los otros homes. Otrosi decimos que si algunt home honrado pidiese merced al rey que estodiese delante cuando él ficiese su testamento vale, maguer non sea hi escripto otro testigo si non el rey tan solamiente.

La especialidad de este testamento radica que, como privilegio del Rey, su permiso suple la falta de capacidad que tiene el incapaz para testar, rebajando también el número de testigos a uno si éste testigo es el Rey que ha accedido a serlo.

Aquí se nota una reminiscencia clara del Testamentum Principi oblatum, introducido por una Constitución de Honorio y Teodosio y que Justiniano recogió en su Código. ${ }^{44}$

El testador presenta al Príncipe, cuando está en el Auditorium, su testamento escrito que después es confiado al Magister Libellorum a fin de que lo conserve en su archivo.

La Ley 6, trata de la forma en que pueden testar los aldeanos:

Aldeano alguno queriendo facer su testamento en escripto, si en aquel logar de él morase non podiere haber siete testigos que sepan escrebir, puede facer su testamento delante cinco testigos que sean llamados et rogados para esto, et que se escriban sus nombres en la carta del testamento; et si por aventura todos cinco non sopiesen escrebir, puédelo escribir el uno dellos, el que los sopiese facer por sí et por los otros. Pero tal testamento como este que se face ante testigos que non son todos letrados, non deben seer fechos en poridat, ante lo deben facer leer paladinamente ante los testigos que se acertaren hi, porque non pueda seer fecho en él ningunt engaño.

En esta Ley, se aprecia una influencia notoria del testamentum ruri conditum, regulado por una Constitución de Justiniano del 534 C 6 , $23,31 .^{45}$

Se reduce la intervención de siete testigos, posiblemente porque en el campo no haya facilidad de encontrarlos, bastando sólo cinco. Cuando el testamento es redactado por escrito, los testigos que sepan escribir tienen que firmar por los que no saben, pero éstos deben conocer la voluntad del testador. 
En la Ley 7 se nos describe la validez del testamento hecho por el padre para sus hijos aunque no esté confeccionado de acuerdo a la regla general:

Acabado testamento es aquel que es fecho en alguna de las maneras que dixiemos en las leyes ante desta, et si de otra guisa lo feciesen non serie valedero. Pero si el padre ficiese testamento en que establesciese por herederos los fijos et los nietos que descendiesen dél ó partiese lo suyo entrellos, maguer en tal testamento non fuesen escriptos mas de dos testigos, valdrie bien asi como si fuese fecho acabadamiente ante siete testigos que posiesen hi sus seellos. Eso mesmo serie quando desta manera el padre ó el abuelo partiese ó ordenase lo suyo por palabra tan solamiente entre sus fijos et sus nietos, faciéndolo ante dos testigos rogados et llamados para esto. Otrosi decimos que si en tal testamento como este fuese ayuntada otra persona extraña á quien heredase el padre en uno con sus fijos, que quanto tañe en la persona del extraño non valdrie el testamento, como quier que en todas las otras cosas que fuesen hi escriptas ó dichas serie valedero. Et aun decimos que si el padre quisiese facer testamento en escripto non guardando todas las cosas que dixiemos que deben hi seer guardadas, poderlo hie facer en dos maneras. La primera es que despues quel testamento sea escripto, debe sobrescrebir el padre deciendo asi: este testamento que fice quiero que sea guardado: otrosi deben decir et sobrescrebir los fijos; este testamento que fizo nuestro padre otorgámoslo. La segunda manera es que si el padre sopiere escrebir que lo pueda facer de su mano, deciendo en él los nombres de todos sus fijos et todo su testamento en qué manera lo face, et como lo ordena, et sobre todo debe asi escrebir; todo quanto en este testamento escrebi quiero que sea guardado. Et en el testamento que fuese fecho en alguna destas dos maneras puede mandar el padre algo á cimos que si el padre quisiese facer testamento en escripto non guardando todas las cosas que dixiemos que deben hi seer guardadas, poderlo hie facer en dos maneras. La primera es que despues quel testamento sea escripto, debe sobrescrebir el padre deciendo asi: este testamento que fice quiero que sea guardado: otrosi deben decir et sobrescrebir los fijos; este testamento que fizo nuestro padre otorgámoslo. La segunda manera es que si el padre sopiere escrebir que lo pueda facer de su mano, diciendo en él los nombres de todos sus fijos et todo su testamento en qué manera lo face, et como lo ordena, et sobre todo debe asi escrebir; todo quanto en este testamento escrebi quiero que sea guardado. Et en el testamento que fuese fecho en alguna destas dos maneras puede mandar el padre algo á home extraño si se quisiere, et puede franquear sus siervos; pero ha meester que quando franqueare sus siervos que tal testamento sea fecho ante dos testigos á lo menos rogados et llamados para esto. 
Este testamento está influenciado por el Testamentum parentis inter liberos, reconocido en una Constitución de Constantino y que Justiniano recopiló en su Código: ${ }^{46}$ si el padre instituye herederos a sus propios hijos, sui o emancipados, o descendientes llamados a heredar $a b$ intestato por successio in locum, su testamento es válido aunque no se sujete a la forma ordinaria, ya sea porque le falte algo o no sea completamente respetada.

El Emperador de Oriente, acoge también en su Código una Constitución de Teodosio II y Valentiniano III del $429^{47}$ y posteriormente en una Novela del 521 establece: destinatarios de las disposiciones testamentarias pueden ser los hijos del causante, los padres, no siendo necesaria la intervención de testigos; el testamento tiene que ser escrito y el testador debe escribir el nombre de los herederos y su cuota y la fecha. No se admiten las disposiciones a extraños, aunque permite las disposiciones singulares a favor de terceros si observan una determinada forma. El testamento puede ser revocado declarándolo ante siete testigos y redactando un nuevo testamento perfecto y solemne. ${ }^{48}$

En la ley 14 se nos describe la forma en que puede hacer testamento el ciego:

\begin{abstract}
El ciego non puede facer testamento fueras ende desta manera: debe llamar siete testigos et un escribano público, et delante dellos debe decir cómo quiere facer su testamento: et otrosi debe nombrar quales son aquellos que establesce por sus herederos et qué es lo que manda, et el escribano debe escrebir todas estas cosas delante los testigos, ó si eran ante escriptas deben seer leidas ante ellos. Et despues que fueren escriptas et leidas debe decir el ciego manifiestamiente como aquel es su testamento, et desi cada uno de los testigos debe escrebir su nombre en aquella carta si sopiere escrebir, et sinon débelo facer escrebir á otro: et también el escribano público que escrebiere la carta como los testigos deben seellar la carta con sus seellos. Et si escribano público non podieren haber, deben haber otro que lo escriba et que sea el ochavo testigo en logar del escribano: et esta guarda debe seer fecha en el testamento del ciego, porque non pueda hiseer fecho engaño.
\end{abstract}

La especialidad de este testamento, en el que se agravan los requisitos, está en que requiere además de los siete testigos, bien un notario, encargado de redactar por escrito las manifestaciones del testador, o 
bien al menos un octavo testigo ante la imposibilidad de que aquél acudiera.

En sus Instituciones, Justiniano se remite a una Constitución promulgada por el Emperador Justino en el 521 (Ins. II. 12.4).

Dicha Constitución, recogida en el Código Justinianeo, ${ }^{49}$ requiere una forma particular en el caso del testamento escrito, y en ella se debió inspirar el Rey Sabio en la Ley expuesta.

Son necesarios siete testigos y un notario (a falta de éste, un octavo testigo), todos deben conocer el contenido del testamento, o que el testador lo exponga después de haberlo escrito o que presente el documento ya redactado y que lo haga leer. El documento, en uno y otro caso, debe ser firmado y sellado por los siete testigos y el notario.

En resumen, como podemos apreciar, los Testamentos especiales que Alfonso X reguló en Las Partidas, están inspiradas en el Derecho Justinianeo.

\section{NOT A S :}

1. Es el caso, por ejemplo, del breve libro de VINOGRADOF, Roman Law in Mediaeval Europe, 2. ${ }^{\mathrm{a}}$ ed., Oxford, 1929 (trad. italiana, 1950).

2. Cfr. J. DAZA, Iniciación histórica al Derecho Romano, Alicante, 1987, p. 202 ss.; Iusta Rei Publicae Gubernatio, Alicante, 1988, passim.

3. Cfr. M. KASER, Das römische Privatrecht II (Die nachklassischer Entwicklungen), 2. ${ }^{\mathrm{a}}$ ed., Munich, 1975, p. 523 ss.

4. Cfr. M. KASER, o.c., p. 476-477.

5. Cfr. KASER, o.c., págs. 549 y siguientes y 495-496.

6. Cfr. KASER, o.c., págs. 514-515.

7. Cfr. KASER, o.c., págs. 466. Justiniano no sólo suprimió la exigencia clásica del ius liberorum a efectos de que la madre pudiera suceder (C.8.58.2; Inst. 3.3.4) sino que en general procuró en el orden sucesorio la equiparación de sexos. 
8. J. DAZA, Iusta rei publicae gubernativo, Alicante, 1988.

9. Los bona vacantia que antes iban siempre a parar al fisco ahora pueden ser también recibidos por los grupos referidos aunque no se considere tal adquisición como herencia (KASER, o.c., pág. 510).

10. OTERO, La mejora, en Anuario de Historia del Derecho Español 33 (1963) pág. 24 y siguientes, señala expresamente esta crisis del testamento. «La crisis de la sucesión testada y del testamento viene confirmada por el codicilo, cuya práctica se extendió sobre todo a partir del siglo III d.C. ...En la época postclásica, precisamente en el momento de su gran difusión, existe una cierta confusión entre testamento y codicilo que nos parece sumamente reveladora. La confusión indica la sustitución del testamento por el codicilo y también la desaparición de la práctica de testar. El aumento del codicilo parece correlativo a la desaparición paulatina del testamento al que llegó a sustituir. Todo esto quiere decir que normalmente se seguía la sucesión legítima, que llegó a prevalecer definitivamente, a la cual sólo se quería corregir en parte por medio del frecuente codicilo. Sólo se harían modificaciones del régimen ab intestato para hacer encargos de confianza... y sobre todo legados, es decir, para donar. De aquí, y como consecuencia de la confusión entre testamento y codicilo, se pasó a llamar al testamento donatio, porque donatio era lo sustancial. Esta sería pues la razón por la cual donatio equivale a testamento en el Derecho euriciano». Por otra parte, el enfoque vulgar, una vez que se borra la significación de la heredis institutio, partió de la idea de que todas las donaciones podian ser clasificadas en dos grupos: el de las revocables (incluyéndose aqui las donaciones mortis causa, el testamento y el codicilo) y el de las irrevocables, es decir, el de aquellas cuya efectividad ha experimentado ya irreversiblemente el donatario. Sobre este enfoque versa el trabajo de SAMPER POLO, La disposición mortis causa en el Derecho romano vulgar, en Anuario citado, 38 1968 , págs. 87 y siguien tes.

11. Esta es la posición de D'ORS, tal como es expuesta en su Derecho privado romano, 4. ${ }^{a}$ ed. Pamplona 1981, pág. 338. V. también del mismo autor, El «Testamentum Porcelli» y su interés para la Historia jurídica en Revue internationale des Droits de l'Antiquité, 1955, pág. 219. La opinión de D'ORS es compartida por SAMPER POLO, tal como puede verse en el escrito de éste antes citado. El Derecho romano vulgar de Occidente pudo haber reconocido por tanto cuatro formas testamentarias: 1) el considerado como testamento de ius civile otorgado ante cinco testigos (= «abierto»), 2) el considerado como testamento del ius praetorium, para el que se requiere la firma de siete testigos (= «cerrado»), 3) el testamento oral (nuncupatio) y 4) el testamento holographum, escrito de propia mano y que no requiere testigos.

12. Eusebio de Cesarea que vivió entre el 260 y el 340, en su biografía —o más bien panegíricodel emperador Constantino, da la noticia de la abolición de las formas aunque no dé más detalles (Vita Constantini IV 26, texto que puede verse en HAENEL, Corpus Legum ab imperatoribus Romanis ante Iustinianum latarum, quae extra constitutionum Codices supersunt, Lipsiae 1857: reimpreso en Aalen 1965, 206); pero la información aparece confirmada por una constitución de Constancio (C.6.23.15) en la que tras suprimir la necesidad de formalidades para la heredis institutio da a entender que otras viejas formas ya no rigen (ademptis his, quorum imaginarius usus est), u por otra de Arcadio y Honorio en la que aluden a una precedente de Constantino (CTh. 4.4.3.2.) sobre testamentos que pudo ser la mencionada por Eusebio de Cesarea. 
13. De ese acercamiento fue consciente el propio Justiniano como lo prueba el pasaje que a propósito precisamente de formas testamentarias se puede leer en sus Instituciones: paulatim tam ex usu hominum quam ex constitutionum emendationibus coepit in unam consonantiam ius civile et praetorium iungi (1.2.10.3).

14. Así por ejemplo en la constitución de Teodosio II del año 424 (CTh. 4.4.7.2): In omni autem genera testamenti, sive in praetorio iure sive civili consistat... id volumus observari... En el propio San Isidoro de Sevilla, dos siglos después, todavía resuena la vieja distinción (V.24.5.6). Pueden verse más referencias en VOCI, Diritto ereditario romano II, Parte speciale, 2. ${ }^{\text {a }}$ ed., Milán 1963, pág. 76, nota 52 .

15. Se trata de la constitución antes citada, recogida en el Código Teodosiano (CTh. 4.4.7.2.). El texto no es fácil de interpretar ya que plantea problemas de no fácil solución. Uno de ellos es el de que se siga hablando de testamentos de cinco y de siete testigos tras la referida constitución de Arcadio y de Honorio de 396. Sobre otros aspectos problemáticos trata VOCI, Diritto ereditario citado, págs 77-78.

16. Los textos correspondientes pueden verse reseñados en VOCI. Diritto ereditario citado, pág. 78, nota 60 .

17. Esta constitución, promulgada en Oriente en el 439, fue extendida a Occidente nueve años más tarde bajo el gobierno de Valentiano III (Nov. Valent. XXVI). Pero antes, en el 446, este mismo emperador había introducido en Occidente en el testamento ológrafo en el que los testigos no son necesarios (Nov. Valent. XXI, 2), forma testamentaria que nunca logró alcanzar vigencia en Oriente.

18. Incluida por Justiniano en su Código (C.6.23.19).

19. Nov. Valent. XXI, 2 .

20. Recuérdese que todo el libro 28 está dedicado a cuestiones testamentarias incluyendo ocho títulos cuyas rúbricas son: I, Qui testamenta facere possunt et quemadmodum testamenta fiant; II, De liberist et postumis heredibus instituendis vel exheredandis; III, De iniusto rupto irrito facto testamento; IV, De his quae in testamento delentur inducuntur vel inscribuntur; V, De heredibus instituendis; VI, De vulgari et pupillari substitutione; VII, De condicionibus institutionum; VIII, De iure deliberandi.

Y que estos temas testamentarios prosiguen en el libro 29 prolongándose luego en los que, también en materia de testamento, se ocupan de disposiciones a título singular.

21. Sus rúbricas son las siguientes: XI, De militari testamento; XII, Quibus non est permissum testamenta facere; XIII, De exheredatione liberorum; XIV, De heredibus instituendis; XV, De vulgari substitutione; XVI, De pupillari substitutione; XVII, Quibus modis testamenta infirmantur; XVIII, De inofficioso testamento; XIX, De heredum qualitate et differentia; XX, De legatis; XXI, De ademptione legatorum; XXII, De lege Falcidia; XXIII, De fideicommisariis hereditatibus; XXIV, De singulis rebus per fideicommissum relictis; XXV, De codicillis.

22. En la edición de KRUEGER se lee en nota a pie de página: libri Graecam constitutionem periisse testantur.

23. En el encabezamiento de esta constitución que es la 15 se lee Imp. Constantinus A. ad populum, pero aparece promulgada siendo cónsules Constancio y Constante lo que permite 
la dotación en 339, es decir, dos años después de haber muerto Constantino. Sobre el error ver la citada edición de KRUEGER (Codex lustinianus, 11. a ed., Berlín 1954). La constitución ha de ser, pues, atribuida a Constancio.

24. Así por ejemplo se remiten a defectos que no acarrean la nulidad del testamento las constituciones $4,7,8$ (rescripto que originará la figura especial del testamento otorgado en tiempo de epidemia), mientras que otras, como la 9 o la 12, señalan defectos insuperables.

25. Es decir, aquel testamento cuyo contenido quiere el testador que permanezca secreto hasta el momento de la apertura, el llamado testamentum inter liberos y el testamento nuncupativo.

26. Las rúbricas de esos doce títulos son las siguientes: I. Qué cosa es testamento; II. De cómo deben ser abiertos los testamentos que son fechos en escripto en poridad; III. De cómo deben seer establecidos los herederos en los testamentos; IV. De las condiciones que pueden seer puestas quando establescen los herederos en los testamentos; V. De como pueden seer establescidos otros herederos en los testamentos en logar de los que hi fueren puestos primeramiente, a que dicen en latin subsitutos; VI. De como los herederos pueden haber plazo para consejarse si tomaran aquel heredamiento en que fueron establecidos por herederos ó non, et de como se debe facer el inventario, et otrosi como debe seer guardada la muger despues de muerte de su marido quando dice que fincó preñada de el; VII. De como et por que rezones puede home desheredar en su testamento a aquel que debia heredar sus bienes; et otrosi por que razones puede perder la heredad aquel que fuere establescido por heredero en ella, manquer nol desheredasen; VIII. De como puede quebrantar el testamento aquel que es desheredado en el a tuerto, a que dicen en latin Querela inoficiosi testamenti; IX. De las mandas que los homes facen en sus testamentos; X. De los testamentos que han de complir las mandas; XI. De como se pueden menguar las mandas et fasta que quantía, aque dicen en latin Falcidia ó debitum bonorum subsidium ó trebellianica; XII. De los escriptos que facen los homes a sus finamientos, a que llaman en latin codicillos.

27. La influencia del Derecho romano justinianeo es aquí clara. Si las Partidas dicen: «Testatio et mens son dos palabras de latín que quieren tanto dezir en romance como testimonio de la voluntad del ome», en las Instituciones de Justiniano (I.2.10 pr.) podemos leer: «Testamentum ex eo appellatur, quod testatio mentis est». Tal derivación, por otra parte, se estima hoy rechazable. Véase por ejemplo, lo que dice SCHULZ en su Derecho romano clásico, Barcelona 1960, págs. 228-229.

28. En el principio de ese título se dice: «Fundamento e rayz de todos los testamentos de qual natura quier que sean es establecer herederos en ellos...".

29. Gregorio López, el célebre comentarista y editor de las Partidas, anota a este respecto: "Potest enim testamentum nuncupativum fieri per scripturam tabellionis, ut in 1.103, título 18 , partida 3; et notat glosa in 1. hac consultissima, et per nuncupationem inglossa 1.C. De testament ( = C.6.23.21.2) ). Con ello da a entender que las palabras "o por escripto» no son un añadido erróneo sino una referencia a la posible intervención de un tabellio, de es decir, de un escribano o notario. (Para la glosa de Gregorio López utilizamos la que acompaña al texto de las Partidas impreso en Salamanca por Andrea de Portanariis en 1555 y reimpreso en Madrid (Bol. Oficial del Estado) en 1974. 
30. La lista de incapaces para actuar como testigos resulta más corta que la que ofrecía Justiniano en sus Instituciones (I.2.10.6), pues alli, aparte de los indicados por las Partidas, tampoco eran tenidos por capaces el sordo, el mundo, el loco y el que ha sufrido la interdictio de sus bienes. Sin embargo, esta ley 1 es claro que no pretendió dar una lista exhaustiva, reservándose ésta para la ley 9 del mismo título (Quáles omes non pueden seer testigos en los testamentos). En ésta de secía: «Testiguar non pueden en los testamentos aquIlos que son dañados por sentencia que fuese dada contra ellos por malas cantigas ó dictados que ficieron contra algunos con entención de enfamarlos; nin otrosi el que fuese condepnado por juicio de los judgadores por razon de algunt mal fecho que ficiese, asi como por furto, ó por homecidio ó por otro yerro semejante destos, ó por mas grave de que fuese dada sentencia contra él; nin otro si ninguno de los que dexan la fe de los cristianos et se tornan moros ó judios, maguer se tornasen despues á nuestra fe, á que dicen en latin apostatas; nin las mugeres, nin los que fuesen menores de catorce años, nin los siervos, nin los mudos, nin los sordos, nin los locos mientre que estodieren en la locura, nin aquellos á quien es defendido que non usen de sus bienes porque son desgastadores dellos en mala manera; ca estos atales non pueden seer testigos en testamentos. Otrosi non lo puede seer home que es siervo de otri; pero si alguno de los testigos que se hi acertaron quando se facie algunt testamento, andaba aquella sazon por home libre, maguer despues fuese fallado en verdat que era siervo, non se embargará el testamento por esta razon».

Otras obras muy relacionadas con las Partidas como son el Doctrinal y las Flores de derecho compuestas por el Maestro jacobo que como se sabe figuró entre los colaboradores de Alfonso $X$, se remiten también a la incapacidad de la mujer para desempeñar el papel de testigo en un testamento. En el Doctrinal (redactado seguramente después de acabadas las Partidas) libro IV, título 2.", capítulo 2.", se lee: «E sobre todo dezimos que mujer de buena fama puede ser testigo en pleyto de otrie fueras ende de testamento» (pág. 274 de la edición de Don Rafael de Ureña y Don Adolfo Bonilla, Obras del Maestro Jacobo de las Leyes, jurisconsulto del siglo XIII, Madrid 1924). Por su parte, en las Flores de Derecho, escritas a lo que parece antes que las Partidas pues todavía vivía Fernando III el Santo, se lee en la ley $2 .{ }^{\text {a }}$ título 8 del libro Il (pág. 130 de la citada edición) al tratar de quienes no pueden ser testigos: «... nen muger en pleyto criminal, nen en testamento". La preocupación por la incapacidad de la mujer en cuanto testigo de un testamento llevó también a los redactores de las Partidas a incluir la curiosa ley 10 (Si puede seer testigo o non en el testamento el que ha natura de varón et de muger): "Hermaphrodita en latín tanto quiere dezir en romance como aquel que ha natura de varón et de muger, et este atal decimos que si tira más a natura de muger que de varón non puede seer testigo en el testamento, más si se acostare mas a natura de varón, entonces bien podría seer testigo en testamento et en todas las otras mandas que ome ficiese». Aunque Gregorio López en sus extensos comentarios no cita los precedentes de la citada ley, éstos son fáciles de precisar. Dos textos del Digesto aluden al caso. El primero es D.1.5.10 (Ulpiano, libro I ad Sabinum): "Quaeritur: hermaphroditum cui comparamus, et magis puto eius sexus aesti mandum, qui in eo prevalet». El segundo es D.22.5.15.1 (Paulo, libro III Sententiarum): «Hermaphroditus an ad testamentum adhiberi possit qualitas sexus incalescentis ostendit».

31. Es decir, la vieja exigencia del testamento del ius praetorium mantenida por Justiniano para el testamento ordinario escrito. Las Partidas precisan que el testigo ha de escribir: "Yo fulano so testigo de deste testamento que lo fizo tal ome (nombrándolo), seyendo yo delante». 
32. Los precedentes estaban en la constitución de Teodosio II y Valentiniano III del año 439 que Justiniano recogió en su Código (C.6.23.21 pr.).

33. El texto es el siguiente: «En escripto queriendo alguno facer su testamento segunt dice en la ley ante desta, si por aventura lo quisiere facer en poridat que non sepa ninguno de los testigos lo que es escripto en él, puédelo facer en esta manera: debe él por su mano mesma escrebir el testamento, si sopiere escrebir, et si non debe llamar otro qual quisiere en quien se fie, et madárgelo escrebir en su poridat, et despues que fuere escripto debe doblar la carta et poner en ella siete cuerdas con que se cierre, de manera que finquen colgadas para poner en ellas siete seellos, et debe dexar tanto pargamino blanco de fuera de la dobladura en que puedan los testigos sobreescribir sus nombres. Et despues desto debe llamar et rogar tales siete testigos como dice en la ley ante desta, et mostrarles la carta doblada, et decirles asi: este es mio testamento, et ruegovos que escribades en él vuestros nombres et quel seelles con vuestros seellos. Et él otrosi debe escrebir su nombre ó facerlo escrebir en fin de los otros testigos, ante ellos deciendo así; otorgo que este es el testamento que yo fulan fice ó mandé escrebir.

34. Tras la justificación de la constitución, Justiniano detallaba casos de paralización momentánea que no debían influir en la validez del testamento y se pronunciaba también sobre el tratamiento a seguir en el supuesto de ausencia definitiva de algunos testigos. He aquí el texto: «Si quid autem necessarium advenerit et in ipsum corpus laborantis respiciens contigerit, id est vel victus necessarii vel petionis oblatio vel medicaminis datio vel impositio, quibus relictis ipsa sanitas testatoris periclitatur, vel si quis necessarius naturas usus ad depositionem superflui ponderis immineat vel testatori vel testibus, non esse ex hac causa testamentum subrertendum, licet morbus comitialis, sed eo quod urget et imminet repleto vel deposito iterumsolita per testamenti factionem adimpleri. Et si quidem a testatore aliquid fiat testibus paulisper reparatis, cum coram his facere aliquid naturale testador erubescat, iterum introduct is testibus consequentiam factionis testamenti procedere. Si tamen in quendam vel quosdam testium aliquid tale contingant, si quidam ex brevi temporis intervallo necessitas potest transire, iterum eorundem testium reversum expectari et solemnia peragi. Si autem longiore spatio refectio fortuiti casus indigeat, et maxime si salus testatoris periclitantis immineat, tunc illo vel illis testibus, circa quos aliquid tale eveniet, separatis alios subrogari et ab eo vel ab eis tam testatorem quam alios testes scitari, si era, quae eorum praesentiam antecedunt, omnia coram eis processissent.

Et si hoc fuerit undique manifestum, tunc eos vel eunt una cum aliis testibus ea quae oportet facere, et si in medio subscriptiones testium iam fuerant subsecutae...

35. (Inst. 11.11) «De Militari Testamento»: Supra dicta diligens observatio in ordinandis testamentis propter nimiam imperitiam constitutionibus principalibus remisa est. Nam quanvis hi neque legitimum numerum testorum adhibuerint neque aliam testamentorum sollemnitatem observaverint, recte nihil minus testantur, «videlicet cum in expeditionibus ocupati sunt: quod merito nostra constitutio induxit. Quoquo enim modo voluntas eius suprema sive scripta inveniatur sive sine escriptura, valet testamentum ex voluntate eius. Illis autem temporibus, per que citra expeditionum necessitatem in aliis locis vel in suis sedibus degunt, minime ad vindicandum tale privilegium adiuvantur: sed testari quidem et si filii familias sunt propter militiam conceduntur, iure tamen communi, ea observatione et in eorum testamentis adhibenda, quam et in testamentis paganorum proxime exposuimus». 
1. Plane de militum testamentis divus Traianus Statilio Severo ita rescripsit: «Id privilegium, quod militantibus datum est, ut quoquo modo facta ab his testamenta rata sint, sic intellegi debet, ut utique prius constare debeat testamentum factum esse, quod et sine scriptura a non militantibus quoque fieri potest. Is ergo miles, de cuius bonis apud te quaeritur, si convocatis ad hoc hominibus, ut volumtatem suam testaretur, ita locutus est, ut declararet, quem vallet sibi esse heredem et cui libertatem tribuere, potest videri sine scripto hoc modo esse testatus et voluntas eius rata habenda est. Ceterum si, ut plerum que sermonibus fieri solet, dixit alicui: "ego te heredem facio» aut «tibi bona mea relinquo», non oportet hoc pro testamento observari. Nec ullorum magis interest quam ipsorum, quibus id privilegium datum est, eiusmodi exemplum non admitti: alioquin non difficulter post mortem alicuius militis testes existerent, qui adfirmarent se audisse dicentem aliquem relinquere se bona, cui visum sit, et per hoc iudicia «vera subvertantur».

2. Quin immo et mutus et surdus miles testamentum facere possunt.

3. Sed hactenus hoc illis a principalibus constitutionibus conceditur, quatenus militant et in castris degunt: post missionem vero veterani vel extra castra si faciant adhuc militantes testamentum, communi omnium civium romanorum iure facere debent. Et quod in castris fecerint testamentum non communi iure, sed quomodo voluerint, post missionem intra annum tantum valebit. Quid igitur, si intra annum quidem decesserit, condicio autem heredi adscripta post annum extiterit? An quasi militis testamentum valeat? Et placet valere quasi militis.

4. Sed et si quis ante militiam non iure fecit testamentum et miles factus et in expeditione degens resignavit illud et quaedam adiecit sive detraxit vel alias manifesta est militis voluntas hoc velere volentis, dicendum est valere testamentum quasi ex nova militis voluntate. 5. Denique et si in adrogationem datus fuerit miles vel filius familias emancipatus est, testamentum eius quasi militis exnova voluntate valet nec videtur capitis deminutione irritum fieri.

6. Sciendum tamen est, quod ad exemplum castrensis peculii tam anteriores leges quam principales constitutiones quibusdam quasi castrensia dederunt peculia, quorum quibusdam permissum erat etiam in potestate degentibus testari. Quod nostra constitutio latius extendens permisit omnibus in his tantummodo peculiis testari quidem, sed iure communi: cuius constitutionis tenore perspecto, licentia est nihil eorum, quae ad praefatum ius pertinent ignorare.

36. C.6. 23 19: el texto es el siguiente: «Omnium testamentorum sollemnitatem superare videatur, quod insertum mera fide precibus inter tot nobiles probatasque personas etiam conscientiam principis tenet. Sicut igitur securus erit, qui actis cuiuscumque indicis aut municipum aut auribus privatorum mentis suae postremum publicavit iudicium, ita nec de eius umquam successione tractabitur, qui nobis mediis, et toto iure, quod nostris est scriptiis constitutum, teste succedit. Nec sane illud heredibus nocere permittimus, si rescripta nostra nihil de eadem voluntate responderint. Voluntates etnim hominum audire volumus, non iubere, ne post sententiam nostram inhibitum videatur commutationis arbitrium, quum hoc ipsum, quod per supplicationem nostris auribus intimatur, ita demum firmum sit, si ultimum comprobatur nec contra iudicium suum defunctus postea venisse detegitur. Ne quid sane praetermisisse credamur huiusmodi institutionis successoribus designatis, omnia quae scriptis heredibus competunt iubemus eos habere nec super bonorum possessionis petitione ullam controversiam nasci, cum pro herede agere cuncta sufficiat, et ius omne ipsa complere aditio videatur. Omnibus etenim praestantum esse censemus, ut libero arbitrio, cui testandi facultas suppetit, successsorem summ oblatis possit precibus declarare, et sta- 
bile sciat esse, quod fecerit, nec institutus heres pertinescat, cum oblatas preces secundum voluntatem defuncti idoneis possit testibus approbare, si ei alia nocere non possunt».

37. «Et ab antiquis legibus et a diversis retro principibus semper rusticitati consultum est et in multis legum subtilitatibus stricta observatio eis remissa est, quod ex ipsis rerum invenimus documentis. Quum enim testamentorum ordinatio sub certa definitione legum instituta est, homines rustici et quibus non est literarum peritia quomodo possunt tantam legum subtilitatem custodire in ultimis suis voluntatibus? Ideo ad Dei humanitatem respicientes necessarium diximus per hanc legem eorum simplicitati subvenire. Sancimus itaque, in omnibus quidem civitatibus et in castris orbis Romani, ubi et leges nostrae manifestae sunt et literarum viget scientia, omnia, quae etiam libris nostrorum Digestorum seu Institutionum, et imperialibus sanctionibus, nostrisque dispositionibus in condendis testamentis cauta sunt, observari nullamque ex praesenti lege fieri innovationem. In illis vero locis, in quibus raro inveniuntur homines litterati, per praesentem legem rusticanis concedimus, antiquam eorum consuetudinem legis vicem obtinere, ita tamen, ut, ubi scientes literas inventi fuerint, septem testes, quos ad testimonium vocari necesse est, adhibeantur et unusquisque pro sua persona subscribat: ubi autem non inveniuntur litterati, septem testes etiam sine scriptura testimonium adhibentes admitti. Si autem in illo loco minime inventi fuerint septem testes, usque ad quinque modis omnibus testes adhiberi iubemus minus autem nullo modo concedimus. Si vero unus aut duo vel plures scierint litteras, liceat his pro ignorantibus litteras, praesentibus tamen, subscriptionem suam imponere, sic tamen, ut ipsi testes cognoscant testatoris voluntatem, et maxime quem vel quos heredes sibi relinquere voluerit, et hoc post mortem testatoris iurati deponant. Quod igitur quisque rusticorum, sicut praedictum est, pro suis rebus disposuerit, hoc omnimodo legum subtilatate remissa, firmun validumque consistat.

38. C.3.36.26. Imp. Constantinus A. ad bassum P.P. Inter omnes duntaxat heredes suos, qui ex quolibet venientes gradu tamen pares videanturesse, vel emancipatos, quos praetor ad successionem vocat, sive coeptum neque impletum testamentum vel codicillus seu epistula parentis esse memoretur, sive quocunque alio modo scripturae quibuscunque verbis vel indiciis inveniantur relictae, iudicio familiae erciscundae, licet ab intestato ad successionem liberi vocentur, servato senatusconsulti auxilio defuncti dispositio custodiatur, et si solemnitate legum huiusmodi dispositio fuerit destituta. Si vero in huiusmodi voluntate designatis liberis alia sit mixta persona, certum est eam voluntatem, quantum ad illa duntaxat permixtam personam pro nullo haberi.

39. C.6.23.21.3. Aquí añade: A parentibus utriusque sexus: Ex imperfecto autem testamento voluntatem tenere defuncti, ni si inter solos liberos a parentibus utriusque sexus habeatur, non volumus. Si vero in huiusmodi voluntate liberis alia sit extranea mixta persona, certum est, eam voluntatem, quantum, ad illam duntaxat permixtam personam pro nullo haberi, sed liberis acrescere.

40. N. 107. A Constantino divae memoriae lex scripta est antiquam sectata simplicitatem, at porro causarum varietas et natura eas frequenter mutans egere leges illas emendatione nostra praeparavit. Dicit itaque lex oportere morientium voluntates, quando sunt parentes, omnibus modis interfilios tenere, et tantum eos erubescit parentes exsistentes, quia eis et claram rerum concedit significationem, dicens, et si non manifestae sunt eorum dispositiones, aperiuntur autem ex quibusdam indiciis et coniecturis et qualibet scriptura, et sic eas valere: et hoc in suis et emancipatis filiis ait; insuper et Thoedosii decernit, non in patribus solum haec disponens, sed etiam in matribus et ascendentibus utriusque naturae. Hanc ap- 
prehendentes licentiam homines in tantam egressi sunt obscuritatem, ut divinantibus magis, quam interpretantibus haec egerent: itaque neque personas scribentes, nequae rerum dicentes notitias, et forte nec quantitatem, tamen dignantur coniecturis et verisimilium ratione talia permittere.

Cap. I. Nos igitur omnia clara et aperta consistere volentes (quid enim sic proprium est legum, sicut claritas, maxime super defunctorum dispositionibus?), volumus: si quis litteras sciens inter filios suos voluerit facere dispositionem, primum quidem eius praescribere tempus deinde quoque filiorum nomina propria manu, ad haec uncias in quibus scripsit eos heredes, non signis numerorum significandas, sed per totas litteras declarandas, ut undique clarae et indubitatae consistant. Si vero etiam rerum voluerit facere divisionem aut quibusdam rebus certis aut omnes aut quasdam institutionum statuere, et harum inscribat(es)significationes, ut eius litteris omnia declarata nullam ulterius contentionem filiis derelinquant. Si tamen aut uxori aut extraneis aliquibus personis voluerit relinquere legata aut fideicommissa aut libertates, et haec propria scripta manu dictaque a testatoribus coram testibus, quoniam omnia consequenter in dispositione posita ipsi et scripserunt et volunt valere, sint firma, nihil minuenda, eo quod videantur in carta scripta reliquam observationem testamentorum non suscipientia, sed hoc solum immutetur, quod eius manus et lingua habet omnem virtutem cartae praebitam.

Cpa. II. Et si quidem usque ad mortem maneat hoc schema, nullus postea deducet testes, quia voluit forte talem voluntatem commutare aut convertere aut aliquid tale facere, cui licuit rumpere, quod factum est, et aliam facere voluntatem declarantem perfectam eius sententiam, quam competit valere. Hoc enim concedimus ei agere, hoc ipsum expressim significantem sub praesentia testium septem, quia etsi fecit quandam talem voluntatem, non tamen valere eam ulterius vult, sed rursus vult aliam facere. Et hanc aut in testamento perfecto faciat omnia testamentorum habente signa, aut in non scripta perfecta voluntate videri eum defunctum esse, prioribus infirmis factis ex secunda eius secundum perfectum testamentum aut voluntatem dispositione.

Cap. III. Quia vero novimus aliquos divisiones facientes inter proprios filios et praeparentes eos his subscribere, et hoc schema suscepimus. Si quis enim dividit proprias res et ipsos filios evocans faciat subscribere divisionibus ipsis, et ratas eas iudicare, et profiteri haec secundum hunc habere modum, sit et hoc firmum in huiusmodoi rerum divisiones secundum nostram constitutionem quam ob hoc posuimus: quam in omnibus, quae in ea continentur, firman esse et per hanc legem sancimus. Si autem et in divisione ipse suscripserit et clara omnia per subscriptionem suam fecerit, sit et hoc ratum, quoniam et hoc iam nostra legislatione continetur. Palam vero est quia in talibus casibus haec lex valebit, quoscumque postea moveri contigerit.

41. C.6.22.8. Imp. Iustinus A. Demostheni. Hac consultissima lege sancimus, ut carentes oculis seu morbo, vel ita nati, per nuncupationem suae condant moderamina voluntatis, praesentibus septem testibus, quos aliis quoque testamentis interesse iuris est, tabulario etiam: ut cunctis ibidem collectis primum ad se convocatos omnes, ut sine scriptis testentur, edoceant, deinde exprimant nomina specialiter heredum et dignitates singulorum et indicia, ne sola nominum commemoratio quidquam ambiguitatis pariat, et ex quanta parte vel ex quotis unciis in successionem admitti debeant, et quod unumquemque legatarium seu fideicommissarium asseque velit; omnia denique palam edicat, quae ultimarum capit dispositionum series lege concessa. Quibus omnibus ex ordine peroratis uno eodemque loco et tempore, sed et tabularii manu conscriptis sub obtentu septem (ut dictum est) testium et 
eorundem testium manu subscriptis, dehinc consignatis tam ab hisdem testibus quam a tabulario, plenum obtinebit robur testantis arbitrium. Quae in eundem modum erunt observanda, quamvis non heredes instituere, sed legata solum vel fideicommissa et in summa quae codicillis habentur congrua duxerit ordinanda. 